\title{
Abscisic Acid Affects Strawberry Fruit Quality
}

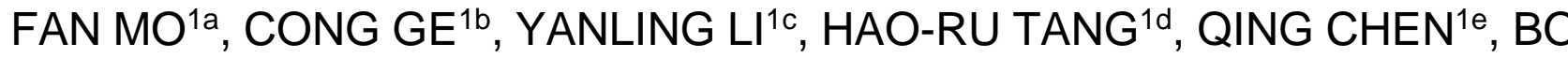

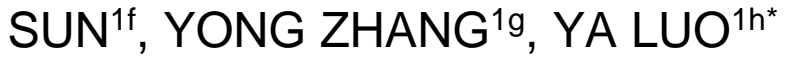 \\ 1Horticultural College, Sichuan Agricultural University, Chengdu 611130, China \\ a853861848@qq.com,b943156105@qq.com,c269825078@qq.com, ${ }^{d} 1048019614 @ q q . c o m$, \\ e303767306@qq.com,f2019704399@qq.com, 13084987@qq.com \\ h*luoya945@163.com
}

${ }^{*}$ Corresponding author, Fan Mo, Cong Ge, and Yan'ling Li contributed equally to this work.

Keywords: abscisic acid application, strawberry ripening, nutritional quality

Introduction:Strawberry is a popular fruit with high visual appeal and a desirable taste ${ }^{[1]}$.that is also rich in vitamins, anthocyanins, flavonoids, and polyphenolics ${ }^{[2,3]}$. In China, the strawberry harvest season ranges from October to May. Normally, a cultivar that produced fruit before the Spring Festival is called "winter strawberry", while one that produces fruit after the Spring Festival is called "spring strawberry". As fewer fruit are produced in winter, the "winter strawberry" is gaining attention from farmers because of its higher economic value. Cultivars that are available earlier in the season result in higher earnings for the farmers. Farmers, therefore, use cultivation techniques to regulate strawberry flowering time and harvest date, including the use of earlier plantings or daughter plants stored at low temperatures.

Cultivation techniques aside, the development and ripening of strawberry fruit are also regulated by plant hormones ${ }^{[4]}$. Abscisic acid (ABA) is an important phytohormone that is the main regulator of strawberry fruit ripening ${ }^{[5,6]}$. ABA application is a potential method for regulating strawberry ripening. The length of fruit growth time is, however, closely related to fruit quality. This directly influences the commercial value of strawberry. It is not currently known whether the shortened growth period affects strawberry fruit quality. Previous studies have shown that exogenous ABA application significantly increased the in vitro anthocyanin content of strawberry ${ }^{[7]}$, but other quality parameters such as weight, soluble solids have not been studied. Therefore, the objective of this study was to investigate the effect of the timing and concentration of ABA application on strawberry fruit ripening. Moreover, the ripening-related quality of strawberry fruit were also investigated and may provide useful information about when and how to apply ABA during strawberry ripening in the field.

\section{MATERIALS AND METHODS}

\section{Plant materials and ABA treatment}

Strawberry (Fragaria ananassa 'Benihoppe') plants were grown in soil in a plastic greenhouse under natural culture conditions during the winter season in Ya'an, China. About 850 secondary flowers on 200 strawberry plants were tagged at flowering. Only targeted fruit were sprayed with $S$-ABA at five different concentrations (20, 25, 30, 35 or $40 \mathrm{mg} / \mathrm{L})$, or with water as the control until run off, at the de-greening (DG, $18 \mathrm{~d}$ after anthesis), white (W, $21 \mathrm{~d}$ after anthesis), and initial red (IR, $23 \mathrm{~d}$ after anthesis) stages.

A randomized complete block design was adopted with three replicates. Fifteen fruits were sampled per experimental treatment. To avoid the non-targeted fruit were sprayed, a very small hand-held sprayer was used. The number of full red strawberries was recorded at 4-d intervals from the beginning of treatment, and full red fruit were harvested for fruit analyses. 


\section{Determination of fruit weight, fruit color, total soluble solids, and titratable acid}

Fruit weights were measured using an electronic scale. Fruit color was measured with a chroma meter (CR-400, Konica Minolta, Japan). Results were presented as $L^{*}$ (brightness) value, hue angle $\left(h^{\circ}\right)$ indicating colour shade and chroma $\left(\mathrm{C}^{*}\right)$ indicative of saturation or colour intensity ${ }^{[8]}$. The soluble solid content (TSS) was measured using a pocket refractometer (PAL-1, Atago, Japan). The titratable acid (TA) content was determined by repeated titrations with $0.1 \mathrm{~mol} / \mathrm{L} \mathrm{NaOH}$ to a faint pink and the malic acid content estimated as described previously ${ }^{[9]}$.

\section{Determination of total anthocyanin content}

Determination of the total anthocyanin content was conducted using the $\mathrm{pH}$ differential method ${ }^{[10]}$. Approximately $5.0 \mathrm{~g}$ of mixed strawberry fruit was extracted with $25 \mathrm{~mL}$ of pre-cooled $1 \%$ $\mathrm{HCl}$-ethanol on ice and centrifuged at $8000 \times g$ for $25 \mathrm{~min}$ at $4^{\circ} \mathrm{C}$. The supernatants were measured for total anthocyanin content. Results were expressed as mg of cyanidin 3-glucoside equivalents per 100 g of FW.

\section{Statistical analysis}

Experiments were performed according to a completely randomized design. ANOVAs were carried out to examine statistical differences between treatments, using the Tukey test. Data were expressed as mean. Statistical differences were evaluated at the $5 \%$ level of significance. All analyses were conducted using SPSS software (Release Version 20; IBM, USA)

\section{RESULTS AND DISCUSSION}

\section{Effect of exogenous ABA on strawberry fruit coloring}

Strawberry is one of the most popular fruits in winter in China. Based on the fruit market, the "winter strawberry" has a higher economic value in China compared with the 'spring strawberry'. Shortening the growth time of strawberry fruit, therefore, conveys a competitive advantage in winter. In the present study ABA clearly accelerated strawberry ripening in both an application concentration and timing dependent manner (Figure 1). We found that the optimal ABA treatment concentration and timing for strawberry is $30 \mathrm{mg} / \mathrm{L} \mathrm{ABA}$ at $\mathrm{DG}, 30 \mathrm{mg} / \mathrm{L}$ and $35 \mathrm{mg} / \mathrm{L} \mathrm{ABA}$ at $\mathrm{W}$, and $40 \mathrm{mg} / \mathrm{L} \mathrm{ABA}$ at IR, which was ready for harvest around 4 to $12 \mathrm{~d}$ or 4 to $8 \mathrm{~d}$ earlier than the control. This also indicates that one time ABA application have obvious positive effect on strawberry ripening. Therefore, ABA application is a useful tool for growers to shorten the growth time of strawberry fruit in the winter.

\section{Effect of exogenous ABA on strawberry fruit weight and quality}

As the fruit growth period is closely related to fruit quality, we examined the effect of a shorter growth period on fruit quality. No effect on fruit weight was observed with ABA application (Table 1). These results are similar to those previously observed in grapes ${ }^{[11,12]}$ and southern highbush blueberries ${ }^{[13]}$. The TSS and TA were important indicators of fruit quality. In this work, ABA treatment had almost no effect on TSS but decreased TA, especially more clear in DG stages (Table 1). These results contradict other study in which ABA significantly increased strawberry TSS and had no effect on TA ${ }^{[14]}$. However, the results were agree with that on citrus where an ABA application could significantly decrease the content of organic acid by promoting the degradation of organic acid ${ }^{[15]}$.

The lightness, color shade and saturation of the strawberry fruit are three important parameters that affect the color of strawberry and are reflected respectively by $L^{*}$ values, $h^{\circ}$ values and $C^{*}$ values. There were no significant differences in color parameters between the control and treated fruit (Table 1). ${ }^{[8]}$ reported that ABA treatment only had little effect on $L^{*}$ values in grapes, but no effect on $h^{\circ}$ values and $C^{*}$ values. 


\section{CONCLUSION}

This study demonstrated that ABA application accelerated strawberry ripening and increased TSS/TA, AsA, TPC, TFC, anthocyanin content, and antioxidant capacity, with no effect on fruit weight and color. Moreover, this suggests that ABA has no effect on yield but may improve fruit quality while shortening the growth period. This field trial offers real insights into the regulation of strawberry fruit ripening and quality by $\mathrm{ABA}$.

\section{Acknowledgements}

Supported by the Scientific Research Foundation for Returned Overseas Chinese Scholars, State Education Ministry and Key projects of Sichuan Provincial Education Department(172A0319).

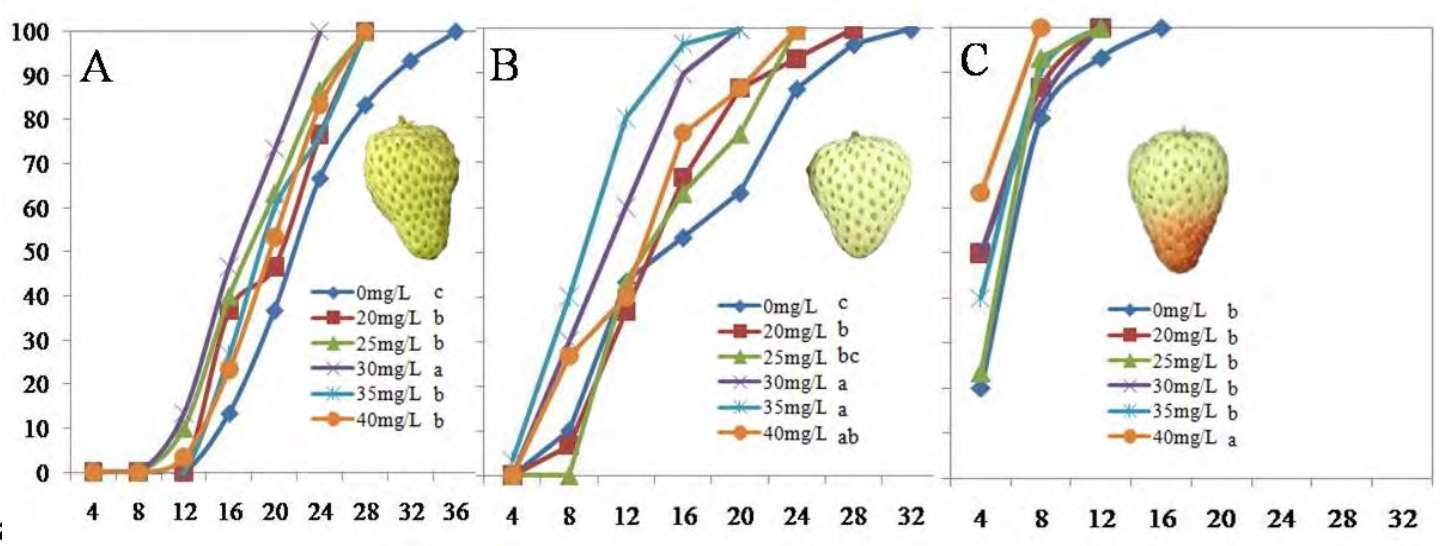

Days after treatment (D)

FIGURE 1 Percentage of full-red strawberry after application of different concentrations of $S$-ABA at the A) degreening, B) white, and C) initial red stages. Each data point represents the mean value of three replicate recordings. Overall significant difference $(\mathrm{P} \leq 0.5)$ is represented by different lower-case letters as determined by Tukey’s test. 
TABLE 1 Effect of application timing and concentration of S-ABA on fruit weight and quality of strawberry

\begin{tabular}{|c|c|c|c|c|c|c|c|c|}
\hline Treated stage & $\begin{array}{c}\text { ABA } \\
\text { concentrations } \\
(\mathrm{mg} / \mathrm{L})\end{array}$ & $\begin{array}{l}\text { Weight } \\
\text { (g) }\end{array}$ & TSS (\%) & TA (\%) & TSS/TA & $L^{*}$ & $H^{\circ}$ & $C^{*}$ \\
\hline \multirow{6}{*}{ DG } & 0 & $20.27 \mathrm{~b}$ & $12.67 \mathrm{a}$ & $0.44 \mathrm{a}$ & $29.19 \mathrm{a}$ & 36.37 a & $29.08 \mathrm{a}$ & $55.38 \mathrm{a}$ \\
\hline & 20 & $22.78 \mathrm{ab}$ & $12.42 \mathrm{a}$ & $0.43 \mathrm{a}$ & $28.96 \mathrm{a}$ & $36.72 \mathrm{a}$ & 28.87 a & $54.55 \mathrm{a}$ \\
\hline & 25 & $22.00 \mathrm{ab}$ & $12.47 \mathrm{a}$ & $0.41 \mathrm{~b}$ & $30.56 \mathrm{a}$ & $35.00 \mathrm{a}$ & $27.01 \mathrm{a}$ & $53.04 \mathrm{a}$ \\
\hline & 30 & $21.07 \mathrm{ab}$ & $12.47 \mathrm{a}$ & $0.38 \mathrm{~b}$ & 32.79 a & $35.10 \mathrm{a}$ & $26.14 \mathrm{a}$ & $54.00 \mathrm{a}$ \\
\hline & 35 & $18.88 \mathrm{~b}$ & $13.08 \mathrm{a}$ & $0.40 \mathrm{~b}$ & $32.81 \mathrm{a}$ & $36.06 \mathrm{a}$ & $27.74 \mathrm{a}$ & $54.12 \mathrm{a}$ \\
\hline & 40 & $21.76 \mathrm{ab}$ & $12.85 \mathrm{a}$ & $0.40 \mathrm{~b}$ & 32.37 a & $35.84 \mathrm{a}$ & $28.07 \mathrm{a}$ & $52.71 \mathrm{a}$ \\
\hline \multirow{6}{*}{ W } & 0 & $19.86 \mathrm{ab}$ & $10.78 \mathrm{a}$ & $0.48 \mathrm{a}$ & $22.52 \mathrm{c}$ & $36.06 \mathrm{a}$ & $28.67 \mathrm{a}$ & $53.16 \mathrm{a}$ \\
\hline & 20 & $21.80 \mathrm{a}$ & $11.88 \mathrm{a}$ & $0.40 \mathrm{c}$ & $29.80 \mathrm{a}$ & $35.20 \mathrm{a}$ & 26.49 a & $53.09 \mathrm{a}$ \\
\hline & 25 & $20.80 a b$ & $10.28 \mathrm{a}$ & $0.46 \mathrm{ab}$ & 23.39 bc & $35.90 \mathrm{a}$ & $27.61 \mathrm{a}$ & $52.74 \mathrm{a}$ \\
\hline & 30 & $18.94 \mathrm{~b}$ & $11.80 \mathrm{a}$ & $0.43 \mathrm{abc}$ & $27.38 \mathrm{abc}$ & $35.00 \mathrm{a}$ & $27.03 \mathrm{a}$ & $52.54 \mathrm{a}$ \\
\hline & 35 & $20.43 a b$ & 11.79 a & $0.43 \mathrm{abc}$ & $27.69 \mathrm{ab}$ & $34.76 \mathrm{a}$ & 26.37 a & $52.82 \mathrm{a}$ \\
\hline & 40 & $20.15 a b$ & $11.72 \mathrm{a}$ & 0.41 bc & $28.48 \mathrm{ab}$ & $35.36 \mathrm{a}$ & 26.65 a & $52.88 \mathrm{a}$ \\
\hline \multirow{6}{*}{ IR } & 0 & $22.03 \mathrm{a}$ & $11.81 \mathrm{ab}$ & $0.51 \mathrm{a}$ & $23.25 \mathrm{c}$ & $33.70 \mathrm{ab}$ & $25.70 \mathrm{a}$ & $51.23 \mathrm{a}$ \\
\hline & 20 & $23.14 \mathrm{a}$ & 10.99 c & $0.45 \mathrm{ab}$ & 24.27 bc & $34.34 \mathrm{a}$ & $26.15 \mathrm{a}$ & $51.00 \mathrm{a}$ \\
\hline & 25 & 23.65 a & $12.06 \mathrm{a}$ & $0.47 a b$ & 25.75 abc & 32.67 b & $24.92 \mathrm{a}$ & $50.29 \mathrm{a}$ \\
\hline & 30 & $21.37 \mathrm{a}$ & 11.18 bc & $0.41 \mathrm{~b}$ & $27.49 \mathrm{a}$ & $33.12 \mathrm{ab}$ & $25.25 \mathrm{a}$ & $50.19 \mathrm{a}$ \\
\hline & 35 & $22.24 \mathrm{a}$ & 11.34 bc & $0.43 \mathrm{~b}$ & $26.42 \mathrm{ab}$ & $33.03 \mathrm{ab}$ & $24.58 \mathrm{a}$ & $49.75 \mathrm{a}$ \\
\hline & 40 & $23.94 \mathrm{a}$ & 11.63 abc & $0.43 \mathrm{~b}$ & $27.15 \mathrm{ab}$ & $33.59 \mathrm{ab}$ & 25.77 a & $50.76 \mathrm{a}$ \\
\hline
\end{tabular}

Note: DG, W and IR means the developmental stage of fruit which was respectively $18 \mathrm{~d}, 21 \mathrm{~d}$ or $23 \mathrm{~d}$ after anthesis. TSS: total soluble solids; TA: titratable acid; TSS/TA: the ratio of TSS to TA. Lower-case letters represent the significant difference $(\mathrm{P} \leq 0.05)$ in columns 


\section{References}

[1] LUO Y.; TANG H.R.; WANG X.R.; ZHANG Y.; LIU Z.J. Antioxidant properties and involved antioxidant compounds of strawberry fruit at different maturity stages. Jouranl of Food, Agricultural and Environment, Helsinki, v9, n.1, p.166-170, 2011.

[2] BASU A.; NGUYEN A.; BETTS N.M.; LYONS T.J. Strawberry as a functional food: an evidence-based review. Critical Reviews in Food Science and Nutrition, Philadelphia, v. 54, n.6, p.790-806, 2014.

[3] GIAMPIERI F.; TULIPANI S.; ALVAREZ-SUAREZ J.M.; QUILES J.L.; MEZZETTI B.; BATTINO M. The strawberry: composition, nutritional quality, and impact on human health. Nutrition, New York, v28, n.1, p.9-19, 2012.

[4] SYMONS G.M.; CHUA Y.J.; ROSS J.J.; QUITTENDEN L.J.; DAVIES N.W.; REID J.B. Hormonal changes during non-climacteric ripening in strawberry. Journal of Experimental Botany, Oxford, v63, n.13, p.4741-4750, 2012.

[5] CHAI Y.M.; JIA H.F.; LI C.L.; DONG Q.H.; SHEN Y.Y. FaPYR1 is involved in strawberry fruit ripening. Journal of Experimental Botany, Lancaster, v62, n.1, p.5079-5089, 2011.

[6] JIA H.F.; CHAI Y.M.; LI C.L.; LU D.; LUO J.J.; QIN L.; SHEN Y.Y. Abscisic acid plays an important role in the regulation of strawberry fruit ripening. Plant Physiology, Rockville, v157, n.1, p.188-199, 2011.

[7] JIANG Y.; JOYCE D.C. ABA effects on ethylene production, PAL activity, anthocyanin and phenolic contents of strawberry fruit. Plant Growth Regulation, Dordrecht, v39, n.2, p.171-174, 2003.

[8]ROBERTO S.R.; ASSIS A.M.D.; YAMAMOTO L.Y.; MIOTTO L.C.V.; SATO A.J.; KOYAMAR.; GENTA W. Application timing and concentration of abscisic acid improve color of 'Benitaka' table grape. Scientia Horticulturae, New York, v.142, n.142, p.44-48, 2012.

[9] HAN Y.S. Food chemical experiment guidance. Beijing: China Agricultural University Press., 1996.

[10] CHENG G.W.; BREEN P.J. Activity of phenylalanine ammonia-lyase (PAL) and concentrations of anthocyanins and phenolics in developing strawberry fruit. Journal of the American Society for Horticultural Science, Alexandria, v116, n.5, p.865-869, 1991.

[11] PEPPI M.C.; FIDELIBUS M.W.; DOKOOZLIAN N.K. Application timing and concentration of abscisic acid affect the quality of 'Redglobe' grapes. Journal of Horticultural Science \& Biotechnology, Ashford, v82, n.2, p.304-310, 2007

[12] SANDHU A.K.; GRAY D.J.; LU J.; GU L. Effects of exogenous abscisic acid on antioxidant capacities, anthocyanins, and flavonol contents of muscadine grape (Vitis rotundifolia) skins. Food Chemistry, Kidlington, v126, n.3, p.982-988, 2011.

[13] BURAN T.J; SANDHU A.K.; AZEREDO A.M.; BENT A.H.; WILLIAMSON J.G.; GU L. Effects of exogenous abscisic acid on fruit quality, antioxidant capacities, and phytochemical contents of southern high bush blueberries. Food Chemistry, Kidlington, v132, n.3, p.1375-1381, 2012.

[14] Ayub R.A.; Bosetto L.; Galvão C.W.; Etto R.M.; Inaba J.; Lopes P.Z. Ascisic acid involvement on expression of related gene and phytochemicals during ripening in strawberry fruit Fragaria $\times$ ananassa cv. Camino Real. Scientia Horticulturae, New York, v.203, p.178-184, 2016. 
[15] WANG X., YIN W., WU J., CHAI L., YI H. Effects of exogenous abscisic acid on the expression of citrus fruit ripening-related genes and fruit ripening. Scientia Horticulturae, New York, v.201, p.175-183, 2016. 